\title{
THE SYSTEM FOR EQUALIZATION OF LOCAL SELF- Government Units REVENUE IN POLAND
}

\author{
PRZEMYSLAW PEST*
}

\section{INTRODUCTION}

Article 166 of the Polish Constitution ${ }^{1}$ distinguishes own tasks and allocated tasks, while art $167 \mathrm{sec} 2$ indicates that revenues of local selfgovernment units (LSGUs) are comprised of own revenues, general subsidies and specific grants from the state budget. These provisions, analysed together, are of importance in delineating the assumed functions of particular types of revenue by local self-government units. The assumed function of own revenues and of the general subsidy is to finance own tasks, while specific grants are designed to fund allocated tasks ${ }^{2}$. In respect of financing own tasks, the primary role is played by own revenues ${ }^{3}$. However, because the sources of own revenues are distributed unevenly across the country, it is necessary for the system of local self-government unit revenues to contain an equalizing mechanism complementing own revenues and allowing local selfgovernment units to finance the performance of own tasks.

The axiological justification for the functioning of this equalization mechanism can be found in the constitutional principles of social justice (art 2 Constitution), the unitary character of the state (art 3 Constitution) and sustainable development (art 5 Constitution). The need for an equalization mechanism is also indicated in art $9 \mathrm{sec} 5$ of the European Charter of Local Self-Government (ECLSG) ${ }^{4}$. Under this provision, the protection of

DOI: $10.1515 /$ wrlae-2015-0054

* PhD in Law, Assistant Professor at the Chair of Financial Law, Faculty of Law, Administration and Economics, University of Wrocław; przemyslaw.pest@uwr.edu.pl

${ }^{1}$ Constitution of the Republic of Poland of 2 April 1997 (Dziennik Ustaw - Official Journal of Laws of the Republic of Poland (hereinafter: Dz. U.) No 78, item 483 with amendments), hereinafter: the Constitution.

${ }^{2}$ The Local Self-Government Revenue Act (Dz. U. 2015, item 513 with amendments) does envision financing of own tasks from targeted subsidies (cf. art 42, 43, 51), but it does not seem that they should be the primary source of financing for own tasks.

${ }^{3}$ Teresa Dębowska-Romanowska, Prawo finansowe. Część konstytucyjna wraz z częśsia ogólna [Financial law. Constitutional part with general part] (C.H. Beck 2010) 231.

${ }^{4}$ European Charter of Local Self-Government, Strasburg, 15 October 1985 (Dz. U. 1994 No 124, item 607, correction Dz. U. 2006 No 154, item 1107). 
financially weaker local authorities' calls for the institution of financial equalisation procedures or equivalent measures which are designed to correct the effects of the unequal distribution of potential sources of finance and of the financial burden they must support. The European Charter of Local SelfGovernment explicitly states there is an obligation for the system of local selfgovernment unit revenues to include a permanent financial equalization system, the function of which is to ameliorate objective differences in revenue and expenses among local self-government units at a given level ${ }^{5}$.

The necessity of a system for equalizing local self-government unit revenues is also indicated in the justification for the Local Self-Government Revenue Act (LSGR Act) presently in force: "The draft bill contains a proposal for strengthening the role of the equalization system, whose task will be to correct the imbalances in revenues of local self-government units with reference to average income across the country adjusted for the relevant territorial unit, i.e. commune, county and province. This system is also important in the light of significant differences among regions in Poland. Regardless of the potential for generating own revenues in a given part of the country, all units of local self-government should be equipped to ensure appropriate social and economic development"6. Another passage emphasizes that "with consideration to the significant discrepancies in revenue across communes, counties and provinces, an appropriate equalization system will be introduced with the task of protecting the economically weakest units" 7 .

The function of equalizing the revenues of local self-government units assumed by the legislator is performed by the general subsidy. This equalizing function of the general subsidy consists in complementing the own revenues of local self-government units with funds from the state budget (vertical equalization) or from the budgets of other local self-government units (horizontal equalization), in order to help all units accomplish their own tasks to a degree that meets at least the minimum standards in conditions of differing potential for self-government entities across the country to generate own revenue. In other words, imbalances in access to potential own revenue sources leads to the necessity of equalizing those revenues to the level assumed by the legislator as sufficient to ensure the potential for all local selfgovernment units to finance the performance of own tasks. The equalizing function of the general subsidy is thus always linked to own revenues (the general subsidy complements own revenues) and own tasks (whose

\footnotetext{
${ }^{5}$ Wiesława Miemiec, 'Europejska Karta Samorządu Terytorialnego jako zespół gwarancji zabezpieczających samodzielność finansową gmin - wybrane zagadnienia teoretycznoprawne' [The European Charter of Local Self-Government as a set of guarantees financial independence of commune - selected theoretical and legal issues] (1997) 10 Samorząd Terytorialny 68.

${ }^{6}$ Justification to the government draft bill of the Local Self-Government Revenue Act, Sejm Paper No 1732/IV term 21.

${ }^{7}$ ibid 6.
} 
performance, alongside own revenues, is financed by the general subsidy). In relations between the state budget and the budgets of LSGUs, the vertical divide is of primary significance. It consists in transfers of money to LSGUs; these transfers constitute state budget expenditures in the legal form of subsidies and grants ${ }^{8}$. The horizontal divide, which is of a complementary nature with respect to the vertical, consists in receiving and redistributing a portion of funds from some LSGUs pursuant to criteria defined by statute, and then transferring them to other LSGUs ${ }^{9}$.

The general subsidy is made up of the equalization component, the balancing component (in respect of provinces - regional) and the educational component ${ }^{10}$. An equalizing function is only performed by two portions of the subsidy - the equalization component, which comes from the state budget, and the portion derived from payments by LSGUs, id est the balancing (regional) portion ${ }^{11}$. Attention is drawn to this fact by the justification for the Local Self Government Revenue Act, which does not list the educational component in the context of the assumed equalizing function performed by the general subsidy: "differences in revenues will be equalized by the equalizing component as well as the balancing component (communes, counties) and regional component (provinces) of the general subsidy"12. In respect of both of the portions their assumed function is the same, whereas they are distinguished by different sources of financing (state budget vs budgets of LSGUs). The assumed function of the educational component is also different. As in the case of the equalization and balancing (regional) components of the general subsidy, it serves as a supplement to the own revenues of LSGUs. The grounds for this supplement is not, however, the need to correct for the potential to generate own revenues, but rather to ensure that LSGUs have sufficient funding to perform tasks related to education. This means that the amount of funding due to a given LSGU is independent of that unit's own revenues, therefore it follows that the educational component does not serve to equalize own revenues. The value of the educational component in the general subsidy is derived from criteria set out in the relevant decree of the minister responsible for matters of education and child welfare, in particular the types of schools and other institutions operated by LSGUs, the professional rank attained by teachers, and the number of pupils attending those schools and institutions ${ }^{13}$. It should be emphasized that

\footnotetext{
${ }^{8}$ Zbigniew Ofiarski, Subwencje $i$ dotacje jednostek samorzadu terytorialnego [General subsidies and specific grants for the local self-government units] (Difin 2002) 24.

${ }^{9}$ Hanna Sochacka-Krysiak, Finanse lokalne [Local finances] (Poltext 1995) 31.

${ }^{10}$ Art 7 sec 1 LSGUR Act.

${ }^{11}$ In the case of communes, this includes from the surplus of the complementary amount of the equalizing component of the general subvention (art 21 sec 1 LSGR Act).

12 Justification to the government draft bill of the Local Self-Government Revenue Act, Sejm Print No 1732/IV term, 6.

${ }^{13}$ Art 28 sec 6 LSGR Act.
} 
what is being discussed here is the assumed function of the educational component in the general subsidy from the perspective of criteria used in determining its amount. From the perspective of LSGU expenditures, the educational component does not differ from other portions of the general subvention as LSGUs are free to dispose of funds received from that portion of the general subsidy as they see fit $^{14}$.

In summarizing the foregoing deliberations it should be concluded that the assumed function of the general subsidy in respect of its equalizing and balancing (regional) components is the aforementioned equalizing function. Prior to proceeding to a presentation and examination of how the equalizing and balancing (regional) components of the general subsidy perform their assumed functions, we should first answer the question of whether the general subsidy should equalize only the uneven access of LSGUs to potential sources of revenue, or whether they should also serve to equalize uneven spending burdens. Invoking art 9 sec 5 of the ECLSG it would seem that equalization applies to both revenues and expenses of particular LSGUs ${ }^{15}$. The problem arises, however, of how to objectively account for uneven expenditure levels when determining the value of the equalization, particularly in light of the absence of legal regulation concerning the standardization of costs for the performance of public tasks by LSGUs. It would seem that one solution is to account for expenditure burdens when calculating the number of residents in a given LGSU, which along with tax revenue levels is used in calculating the level of equalization. Taking into account particular expenditure needs should primarily affect large cities in which many people using communal services do not have a place of residence. The proposed mechanism can take the form of a population conversion factor, such as the one which was applied under the Act on financing communes and the Local Self-Government Unit Revenue Act in

\footnotetext{
${ }^{14}$ Art 7 sec 3 LSGR Act.

15 Andrzej Niezgoda, 'Subwencja ogólna i wpłaty jednostek samorządu terytorialnego do budżetu państwa jako elementy finansowego mechanizmu wyrównawczego' [The general subsidies and payment of local self-government units to the state budget as part of the financial equalization mechanism] in Jolanta Gliniecka, Edward Juchniewicz, Tomasz Sowiński (eds) Finanse publiczne jednostek samorządu terytorialnego. Źródła finansowania samorządu terytorialnego we współczesnych regulacjach prawnych [Public finances of local self-government units. Sources of financing of local government in modern legal regulations] (CeDeWu 2014) 71-72.
} 
effect during the period $1999-2003^{16}$, and which is successfully employed in Germany ${ }^{17}$.

A doctoral discourse will be conducted using a legal-dogmatic method, therefore, on analysis of the legal regulations.

\section{EquALIZATION COMPONENT OF THE GENERAL SUBSIDY}

The primary role in equalization of objective inequalities in the level of own revenues generated by LSGUs is - and should be - played by the equalization component of the general subsidy coming from the state budget. In accordance with the constitutional principle of adequacy, it is the State which bears the burden of ensuring that LSGUs participate in public revenues to such an extent as necessary for them to maintain at least a minimum of standards in the performance of the public tasks assigned to them ${ }^{18}$. The idea is for the residents of every LSGU in the unitary state of Poland to have access to public services provided by those entities of a similar standard and at a similar price ${ }^{19}$. With a view to the previously-mentioned constitutional principles of social justice (art 2 Constitution), the unitary character of the state (art 3 Constitution) and sustainable development (art 5 Constitution), it is impermissible for there to exist significant disproportions in the quality and level of communal services provided by LSGUs around the country. The assumed function of the general subsidy, i.e. equalization, is supposed to prevent this from occurring. Whether that function is, in fact, carried out is decided by the criteria for equalization that are adopted.

Since the equalizing and balancing (regional) components of the general subsidy are supposed to equalize the uneven distribution of own incomes around the country, the base for calculating the value of the equalization should be the amount of the own revenues belonging to a given

\footnotetext{
16 The Commune Financing Act of 10 December 1993 (Dz. U. No 129, item 600 with amendments) in art 15 the Local Self-Government Revenue Act of 26 November 1998 in the years 1999-2003 (Dz. U. No 150, item 983 with amendments) in art 22 divided communes into three groups based on population: 1) for communes with fewer than 5,000 residents the population conversion factor was also 5,$000 ; 2$ ) for communes with between 5,000 and 10,000 the population conversion factor was equal to the number of residents; 3 ) for communes with over 10,000 residents, the population conversion factor was based on a special table under which the largest cities (over 300,000 residents) had a conversion factor based on the formula $354,000+125 \%$ of the number of residents over 300,000 .

${ }^{17}$ Cf. Joanna Mackiewicz-Łyziak, Elżbieta Malinowska-Misiąg, Wojciech Misiąg, Marcin Tomalak, Wyrównywanie dochodów jednostek samorządu terytorialnego. Możliwości wykorzystania w Polsce doświadczeń niemieckich krajów związowych [Equalization of local self-government units revenue. Possibilities of using in Poland experience of the German federal states] (Instytut Badań Nad Gospodarką Rynkową 2008) 155-156.

${ }^{18}$ Dębowska-Romanowska (n 4) 244.

19 Wiesława Miemiec, Prawne gwarancje samodzielności finansowej gminy w zakresie dochodów publicznoprawnych [Legal guarantees of financial independence of the communities in public revenues] (Kolonia Limited 2005) 134.
} 
LSGU. Comparison of the amount of the own revenues generated by particular LSGUs at a given level should allow for determining a particular average level of those revenues, in order for those LSGUs below the average to receive equalization from the equalizing and balancing (regional) components of the general subsidy.

Enumerations of the own revenues of communes, counties and provinces are contained in art 4, art 5 and art 6 LSGUR Act. These revenues can be classified into one of four basic categories: revenues from public law tributes, which include revenues from local taxes and fees, as well as shares in revenues from income tax, income generated by assets, payments from organizational entities and self-government juridical persons, as well as other incomes like inheritances, bequests and donations to the benefit of LSGUs ${ }^{20}$.

It should be emphasized that ameliorating differences in levels of own revenues generated by LSGUs of a given level on a national scale concerns only public law own revenues, and not private law own revenues. This is a result of the constitutional principle of adequacy, which in art $167 \mathrm{sec} 1$ of the Constitution obliges the State to ensure participation for LSGUs in public revenues in a manner adequate to the tasks assigned to them. The use of the phrase "public revenues" in this provision should be understood to mean that only in respect of public law revenues does the State have a duty to guarantee them to a given local self-government to the degree that allows it to perform its tasks ${ }^{21}$.

Equalization of own revenues in the legal form of the equalizing and balancing (regional) components of the general subsidy will concern imbalances in public law revenues across the country, and thus primarily revenue generated by public law tributes. It is precisely the level of revenues from public law tributes that leads to disproportions in own income levels among LSGUs. The uneven distribution of revenues from public law tributes is most often the result of objective factors over which local self-government units have no influence: geographical location, climate conditions, the presence or absence of raw materials, the quality of soil, and attractiveness for tourists. What follows is that it is precisely the level of own revenues from public law tributes collected by LSGUs which should be used as the criterion for equalization. Such a construction of the equalizing and balancing (regional) components of the general subsidy facilitates performance of the assumed function of those portions of the general subsidy.

In accordance with art $20 \mathrm{sec} 1$, art $22 \mathrm{sec} 1$ and art $24 \mathrm{sec} 1$ LSGUR Act, the equalizing component of the general subsidy from the state budget

\footnotetext{
${ }^{20}$ Cf. Rafał Kowalczyk in Ryszard Mastalski, Eugenia Fojcik-Mastalska (eds), Prawo finansowe [Financial law] (Wolters Kluwer 2013) 461 et seq.

21 Wiesława Miemiec, 'Artykuł 167' [Article 167] in Jan Boć (ed.), Konstytucje Rzeczypospolitej oraz komentarz do Konstytucji RP z 1997 roku [Constitutions of the Republic of Poland and the commentary to the Constitution of 1997] (Kolonia Limited 1998) 263.
} 
earmarked for LGSUs is composed of the base amount and a supplementary amount. In calculating the base amount of the general subsidy two criteria are taken into account: the amount of tax revenues and the number of residents in a given LSGU. The concept of "tax revenues" gives rise to certain doubts of a terminological nature, as alongside revenues from local taxes the legislator also includes fees and participation in revenue from income taxes (and in respect of counties and provinces - only that last category); nevertheless, the solution itself should be assessed positively ${ }^{22}$. As has already been indicated, calculation of the value of equalizing funds that a given LGSU should receive is to be based on the value of public law tributes constituting public law revenues of that particular unit. Indeed, it is the disproportions in the level of revenues from public law tributes which are the cause of the equalization system, which is designed to eliminate those imbalances. The construction adopted for calculating the value of the base amount of the equalizing component in the general subsidy thus performs the assumed function of the general subsidy, and it therefore follows that the assumed and the performed function are one and the same.

Equalization of the revenues of LSGUs cannot, however, lead to an extreme form of egalitarianism and a drive to make equal the level of revenues generated by all LSGUs on a given level across the country. This would serve to sap local authorities' motivation to stimulate economic growth locally ${ }^{23}$. For this reason the legislator decided to limit the maximum extent of equalization. In the case of communes, a given unit does not receive the base amount of the equalizing component in the general subsidy if its tax revenues are greater than $92 \%$ of the average tax revenues for all communes ${ }^{24}$. However, such a mechanism limiting the maximum level of equalization is not to be found in regulations concerning counties and provinces. In the subject literature this aspect of the general subsidy is at times said to perform a separate stimulating function ${ }^{25}$.

In respect of the supplemental amount of the equalizing component in the general subsidy, whether a given commune receives this funding depends on the population density of the commune in comparison to the average

\footnotetext{
${ }^{22}$ Doubts are raised by art $20 \mathrm{sec} 3$ LSGR Act, which excludes from the catalogue of communal tax revenues receipts from the inheritance and gift tax, as well as from the market, local, health spa, and dog taxes. These tributes are not, however, of significance in generating meaningful disproportions in the level of own revenues generated by communes at the national level.

${ }^{23}$ Beata Guziejewska, 'Podstawowe założenia subwencji ogólnej dla jednostek samorządu terytorialnego w Polsce na tle konstrukcji teoretycznych` [The basic assumptions of general subsidies for local self-government units in Poland on the background of theoretical constructions] (2004) 11 Samorząd Terytorialny 42; Paweł Swianiewicz, 'Transfery z budżetu państwa dla samorządów lokalnych ' Transfers from the state budget for the local governments] (2003) 1 Studia Regionalne i Lokalne 99.

${ }^{24}$ Art $20 \mathrm{sec} 2$ LSGR Act.

${ }^{25}$ Elżbieta Kornberger-Sokołowska, Finanse jednostek samorzadu terytorialnego [Local self-government units finance] (LexisNexis 2012) 113.
} 
population density of the country; the upper limit of the equalization is, in turn, dependent on the value of tax revenues collected by a given commune ${ }^{26}$. In respect of counties, the unemployment rate is the decisive factor as to whether a county receives the supplemental amount ${ }^{27}$. As for provinces, the value of tax revenues plus number of residents in the province (which cannot exceed 3 million $)^{28}$. This means that in respect of the supplemental amount of the equalizing component in the general subsidy for communes and provinces, the value of public law tributes is taken into account when calculating the extent of equalization. What follows is that, in respect of the supplemental amount of the equalizing component in the general subsidy for communes and provinces, the assumed function of the general subsidy is in fact also performed. This is different in the case of counties, where the value of tax revenues is not factored into calculations of the supplemental amount.

\section{The BALANCING (REgionAL) COMPONENT OF THE GENERAL SUBSIDY}

Along with the equalizing component, the second part of the general subsidy, whose assumed function is to ameliorate the effects of the uneven distribution of own revenue sources, is the balancing (regional) component. Distinctly from the equalizing component, which comes entirely from the state budget, the balancing (regional) component is taken from payments made by LSGUs within the framework of the vertical equalization system, also referred to as the correctional-equalization mechanism ${ }^{29}$. As scholars of financial law indicate, the vertical equalization system is intended to prevent those differences that are of an extreme nature, but not every example of disproportion in own revenues.

The vertical equalization system is composed of two stages. In the first, LSGUs defined by statute make equalizing payments to the state budget. In this manner, the revenues of LSGUs exceeding levels defined by the legislator are collected by the State. The second stage entails transfer of the proceeds of such payments in the legal form of the equalizing component (in the case of provinces - regional) in the general subsidy, to LSGUs indicated using statutorily defined criteria. This is therefore not a "pure" system of vertical equalization, such as in the case of a self-government equalization fund remaining under the control of self-government entities ${ }^{30}$. The transfer

\footnotetext{
${ }^{26}$ Art 20 sec 7-9 LSGR Act.

27 Art 22 sec 7-8 LSGR Act.

${ }^{28}$ Art 24 sec 7-9 LSGR Act.

${ }^{29}$ See: Teresa Dębowska-Romanowska (n 4) 244.

30 ibid.
} 
of equalizing funds in the legal form of the balancing (regional) component in the general subsidy is performed via the state budget ${ }^{31}$.

The value of tax revenues that determined the value of the equalization within the framework of the equalizing component in the general subsidy is used here to identify LSGUs obliged to remit equalization payments ${ }^{32}$. Payments made by LSGUs are transferred via the state budget to LSGUs in the legal form of the balancing (regional) component of the general subsidy. It would thus seem that, since the assumed function of the general subsidy is to correct the effects of the unequal distribution of own revenues across the entire country, then the criteria used for identifying beneficiaries of the balancing (regional) component in the general subsidy should also be based on the own revenues of LSGUs from public law tributes. In this manner the assumed function of the balancing (regional) component in the general subsidy would be performed.

Under current law, following verdicts of the Constitutional Tribunal addressing the vertical equalization system ${ }^{33}$ and the passing of temporary legislation governing that system at the provincial level ${ }^{34}$, the decision as to which LGSUs will receive the balancing (regional) component in the general subsidy will primarily depend on selected expenditures and (less frequently) selected revenues of those units. In respect of communes, as much as $75 \%$ of the balancing component of the general subsidy is transferred on the basis of a selectively applied expenditures criterion, such as expenditures on housing subsidies $^{35}$. The remaining $25 \%$ is divided up according to a selectively applied revenue criterion, i.e. revenues from participation in receipts from personal income tax, agriculture tax and forest tax. In the case of counties, disbursement of $76 \%$ of the balancing component in the general subsidy is determined by selected county expenditures, primarily $(60 \%)$ expenses on road network maintenance, and $24 \%$ is transferred on the basis of the amount

\footnotetext{
${ }^{31}$ Wiesława Miemiec, 'Transfery środków pieniężnych pomiędzy budżetem państwa a budżetami jednostek samorządu terytorialnego - wybrane aspekty finansowoprawne' [Transfers between the state budget and the budgets of self-government units - selected financial aspects] (2010) 1-2 Finanse Komunalne 73.

${ }^{32}$ Art $29 \mathrm{sec} 1$, art $30 \mathrm{sec} 1$ and art 70a sec 1 LSGR Act.

33 Cf. Przemysław Pest, 'Wyrównywanie poziome dochodów jednostek samorządu terytorialnego (,janosikowe”) - kierunki zmian' [The horizontal alignment of local selfgovernment units incomes ("janosikowe") - trends] in Jolanta Gliniecka, Edward Juchniewicz, Tomasz Sowiński (eds) Finanse publiczne jednostek samorządu terytorialnego. Źródła finansowania samorzadu terytorialnego we współczesnych regulacjach prawnych [Public finances of local self-government units. Sources of financing of local government in modern legal regulations] (CeDeWu 2014) 99 et seq.; Wiesława Miemiec, Przemysław Pest, 'Wyrównywanie poziome dochodów jednostek samorządu terytorialnego ("janosikowe") w orzecznictwie Trybunału Konstytucyjnego' [The horizontal alignment of local selfgovernment units incomes ("janosikowe") in the Constitutional Tribunal jurisprudence] in Marcin Smaga, Mateusz Winiarz (eds), Dyscyplina finansów publicznych. Doktryna, orzecznictwo, praktyka [The discipline of public finances. The doctrine, case law, practice] (C.H. Beck 2015) 376 et seq.

${ }^{34} \mathrm{Cf}$. arts $70 \mathrm{a}-70 \mathrm{c}$ LSGR Act.

${ }^{35}$ Art 21 a sec 1 LSGR Act.
} 
of revenues generated by a given county ${ }^{36}$. In turn, for provinces, in accordance with temporary regulation in effect for the period 2015-2019, the division of the regional component of the general subsidy is determined in $52 \%$ by the unemployment rate and $48 \%$ by the amount of tax revenues generated by the province ${ }^{37}$.

Assuming, as has already been mentioned, that the function of the equalizing and balancing (regional) components of the general subsidy is to complement the own revenues of LSGUs in conditions of differentiated levels of own revenues around the country, the base for calculating the level of equalization should be the public law own revenues of LSGUs. It is precisely the disproportion in the level of own revenues among LSGUs at a given level that determines the necessity of the existence of an equalization system in the legal form of a general subsidy. It follows that the adopted construction of the balancing (regional) component of the general subsidy, based on selected expenditures and selected revenues of LSGUs does not facilitate the achieving of the assumed function of the general subsidy. The criteria for determining the beneficiaries of the balancing (regional) component in the general subsidy should be the value of own revenues from tributes received by LSGUs. Differentiating expenditure needs, as indicated by art $9 \sec 5$ ECLSG, should be taken into account within the population criterion, and thus in the second - alongside the criterion of tax revenues - element in calculation of the balancing (regional) component in the general subsidy. As was indicated in the first part of the article, the population criterion can take the legal form of the population conversion factor already functioning within the Polish system for revenues of LSGUs. Under present law, the unequal distribution of own revenues across the country is taken into account when determining LSGUs obliged to pay into the state budget funds later earmarked for the balancing (regional) component in the general subsidy, but not when dividing that component among LSGUs.

\section{CONCLUSION}

The equalization function in the system of revenues of LSGUs is performed by the equalizing and balancing (regional) components of the general subsidy, which is indicated in the justification to the present LSGU Revenue Act. This equalization function consists in complementing own revenues of LSGUs using funds from the state budget (vertical equalization) or the budgets of other LSGUs (horizontal equalization), to facilitate the performance by those entities of own tasks to at least a minimum level of standards, in conditions of differing potential to generate own revenues by

\footnotetext{
${ }^{36}$ Art 23a sec 1 LSGR Act.

${ }^{37}$ Art 70b LSGR Act.
} 
LSGUs around the country. The normative justification for the necessity of equalization LSGUs' own revenues can be found in the constitutional principles of social justice (art 2 Constitution), unitary character of the state (art 3 Constitution) and sustainable development (art 5 Constitution), as well as in art 9 sec 5 ECLSG. In order for the assumed equalizing function of the general subsidy to be performed, the primary criteria in determining the value of the equalization should be the amount of own revenues generated by public law tributes paid to particular LSGUs. The equalizing component in the general subsidy, applying tax revenues as the criterion of equalization, performs the assumed function of the general subsidy. However, in respect of the balancing (regional) component in the general subsidy, the criteria for equalizing are selected expenditures and revenues of LSGUs. As a result, the balancing (regional) component does not perform the assumed function of the general subsidy.

\section{References}

Dębowska-Romanowska Teresa, Prawo finansowe. Część konstytucyjna wraz z częścia ogólna [Financial law. Constitutional part with general part] (C.H. Beck 2010)

Guziejewska Beata, 'Podstawowe założenia subwencji ogólnej dla jednostek samorządu terytorialnego w Polsce na tle konstrukcji teoretycznych' [The basic assumptions of general subsidies for local self-government units in Poland on the background of theoretical constructions] (2004) 11 Samorząd Terytorialny

Kornberger-Sokołowska Elżbieta, Finanse jednostek samorzadu terytorialnego [Local self-government units finance] (LexisNexis 2012)

Kowalczyk Rafał in: Ryszard Mastalski, Eugenia Fojcik-Mastalska (eds), Prawo finansowe [Financial law] (Wolters Kluwer 2013)

Mackiewicz-Łyziak Joanna, Malinowska-Misiąg Elżbieta, Misiąg Wojciech, Tomalak Marcin, Wyrównywanie dochodów jednostek samorzadu terytorialnego. Możliwości wykorzystania w Polsce doświadczeń niemieckich krajów związowych [Equalization of local self-government units revenue. Possibilities of using in Poland experience of the German federal states] (Instytut Badań Nad Gospodarką Rynkową 2008)

Miemiec Wiesława, `Artykuł 167` [Article 167] in Boć Jan (ed.), Konstytucje Rzeczypospolitej oraz komentarz do Konstytucji $R P \quad z \quad 1997$ roku [Constitutions of the Republic of Poland and the commentary to the Constitution of 1997] (Kolonia Limited 1998)

Miemiec Wiesława, 'Europejska Karta Samorządu Terytorialnego jako zespół gwarancji zabezpieczających samodzielność finansową gmin - 
wybrane zagadnienia teoretycznoprawne' [The European Charter of Local Self-Government as a set of guarantees financial independence of commune - selected theoretical and legal issues] (1997) 10 Samorząd Terytorialny Miemiec Wiesława, Prawne gwarancje samodzielności finansowej gminy w zakresie dochodów publicznoprawnych [Legal guarantees of financial independence of the communities in public revenues] (Kolonia Limited 2005) Miemiec Wiesława, 'Transfery środków pieniężnych pomiędzy budżetem państwa a budżetami jednostek samorządu terytorialnego - wybrane aspekty finansowoprawne' [Transfers between the state budget and the budgets of self-government units - selected financial aspects] (2010) 1-2, Finanse Komunalne

Miemiec Wiesława, Pest Przemysław, 'Wyrównywanie poziome dochodów jednostek samorządu terytorialnego ("janosikowe") w orzecznictwie Trybunału Konstytucyjnego' [The horizontal alignment of local selfgovernment units incomes ("janosikowe") in the Constitutional Tribunal jurisprudence] in Smaga Marcin, Winiarz Mateusz (eds), Dyscyplina finansów publicznych. Doktryna, orzecznictwo, praktyka [The discipline of public finances. The doctrine, case law, practice] (C.H. Beck 2015)

Niezgoda Andrzej, 'Subwencja ogólna i wpłaty jednostek samorządu terytorialnego do budżetu państwa jako elementy finansowego mechanizmu wyrównawczego' [The general subsidies and payment of local selfgovernment units to the state budget as part of the financial equalization mechanism] in Gliniecka Jolanta, Juchniewicz Edward, Sowiński Tomasz (eds) Finanse publiczne jednostek samorzadu terytorialnego. Źródła finansowania samorzadu terytorialnego we wspótczesnych regulacjach prawnych [Public finances of local self-government units. Sources of financing of local government in modern legal regulations] (CeDeWu 2014) Ofiarski Zbigniew, Subwencje i dotacje jednostek samorzadu terytorialnego [General subsidies and specific grants for the local self-government units] (Difin 2002)

Pest Przemysław, 'Wyrównywanie poziome dochodów jednostek samorządu terytorialnego (,janosikowe") - kierunki zmian` [The horizontal alignment of local self-government units incomes ("janosikowe") - trends] in Gliniecka Jolanta, Juchniewicz Edward, Sowiński Tomasz (eds) Finanse publiczne jednostek samorządu terytorialnego. Źródta finansowania samorządu terytorialnego we współczesnych regulacjach prawnych [Public finances of local self-government units. Sources of financing of local government in modern legal regulations] (CeDeWu 2014)

Sochacka-Krysiak Hanna, Finanse lokalne [Local finances] (Poltext 1995) Swianiewicz Pawel, 'Transfery z budżetu państwa dla samorządów lokalnych ' Transfers from the state budget for the local governments] (2003) 1 Studia Regionalne i Lokalne 